Rev. Int. Contam. Ambie. 36 (4) 1019-1025, 2020

https://doi.org/10.20937/RICA.53648

\title{
MANUFACTURE OF LIGHTWEIGHT PREFABRICATED PANELS EMPLOYING MINE TAILINGS
}

Fabricación de paneles prefabricados ligeros utilizando jales mineros

\author{
Fermín RAMÍREZ-CRESCENCIO, Jaime PARRA-VÉJAR, Verónica LOERA-CASTAÑEDA, \\ Luis Antonio AGUILAR-PÉREZ and Ignacio VILLANUEVA-FIERRO*
}

Instituto Politécnico Nacional, CIIDIR Unidad Durango, calle Sigma 119, Fraccionamiento 20 de Noviembre II, 34220, Durango, Durango, México.

*Author for correspondence: ifierro62@yahoo.com

(Received: June 2019; accepted: March 2020)

Key words: tailings reutilization, foamed concrete, fiber reinforced concrete.

\begin{abstract}
The present study describes the incorporation of mine tailings from the silver mine $\mathrm{La}$ Guitarra in the manufacture of lightweight prefabricated panels (LPPs). Tailings have concentrations of heavy metals below the maximum permissible levels according to Mexican regulations. Their acidity potential (AP) of $2.22 \mathrm{~kg}$ of $\mathrm{CaCO}_{3}$ per tailings ton, along with their lack of neutralization potential (NP), indicates a possibility for the generation of acid mine drainage (AMD). It was reported that concrete could be employed to prevent AMD, thus we proposed to stabilize mine tailings with different concrete ratios and employ these mixtures to fabricate concrete panels. To obtain lightweight panels, a foaming agent was added to the tailings/concrete mixture. Then, a fiberglass mesh was employed to reinforce the final structure. The resulting LPPs (dimensions: $254 \times 139.7 \times 12.7 \mathrm{~mm}$ ) showed a flexural strength of $5.80 \pm 0.06 \mathrm{MPa}$, bulk density of $712 \pm 104 \mathrm{~kg} / \mathrm{m}^{3}$, thermal conductivity of $0.159 \pm 0.004 \mathrm{~W} / \mathrm{m} \mathrm{K}$, mass water absorption of $59 \pm 10 \%$, and net neutralization potential $(\mathrm{NNP}=\mathrm{NP} / \mathrm{AP})>1.2$. According to Mexican regulations, these LPPs are not potential generators of AMD.
\end{abstract}

Palabras clave: reuso de jal de mina, concreto celular, concreto reforzado con fibra.

\section{RESUMEN}

El presente estudio describe la incorporación de jales mineros de la mina de plata $\mathrm{La}$ Guitarra en la fabricación de paneles prefabricados ligeros (PPL). Estos jales tienen concentraciones de metales pesados inferiores al límite máximo permisible de acuerdo con la normatividad mexicana. Sin embargo, su potencial de acidez (PA) de $2.22 \mathrm{~kg}$ de $\mathrm{CaCO}_{3}$ por tonelada de jal, aunado a la ausencia de potencial de neutralización (PN), indica que pueden generar drenaje ácido. Se ha informado que el concreto se puede utilizar para prevenir la generación de drenaje ácido, por lo que se propuso estabilizar los jales mineros con diferentes proporciones de concreto y emplear estas mezclas para fabricar paneles de concreto. Para obtener paneles ligeros se añadió un agente espumante a la mezcla de jales/concreto y se utilizó una malla de fibra de vidrio para reforzar la estructura final. Los PPL resultantes (dimensiones: $254 \times 139.7 \times 12.7 \mathrm{~mm}$ ) 
mostraron una resistencia a la flexión de $5.80 \pm 0.06 \mathrm{MPa}$, densidad aparente de $712 \pm$ $104 \mathrm{~kg} / \mathrm{m}^{3}$, conductividad térmica de $0.159 \pm 0.004 \mathrm{~W} / \mathrm{m} \mathrm{K}$, absorción de agua en masa de $59 \pm 10 \%$, y potencial neto de neutralización $(\mathrm{PNN}=\mathrm{PN} / \mathrm{PA})>1.2$. De acuerdo con la normatividad mexicana, este valor de PNN implica que los PPL no son potenciales generadores de drenaje ácido.

\section{INTRODUCTION}

There is a growing interest in the development of sustainable options for the mining activity (Gorman and Dzombak 2018). Therefore, management of mining waste has become increasingly important (Aznar-Sánchez et al. 2018). Mine tailings are produced after separation of the valuable products from a mineral ore. A 2016 estimate calculates their production rate from five to 14 billion tons per year (Schoenberger 2016). Large companies store the mine tailings behind dammed impoundments, often termed as tailing ponds or tailing dams (Kossoff et al. 2014). Unfortunately, the frequency of dam failures is high resulting in both economic and environmental issues (Páez-Osuna et al. 2015, Schoenberger 2016, Jain and Das 2017).

The chemical composition of tailings depends on several factors of the mineralogy of the ore body, the processing fluids used to extract the economic metals, the efficiency of the extraction process, and the degree of weathering during storage (Kossoff et al. 2014). The presence of sulfide minerals is common, such as pyrite $\left(\mathrm{FeS}_{2}\right)$, pyrrhotite $\left(\mathrm{Fe}_{1-\mathrm{x}} \mathrm{S}\right)$, galena $(\mathrm{PbS})$, sphalerite $(\mathrm{ZnS})$, chalcopyrite $\left(\mathrm{CuFeS}_{2}\right)$, or arsenopyrite (FeAsS). Sulfide minerals lead to the formation of acid mine drainage (AMD) by exposition to atmospheric oxygen, oxygenated waters, and bacteria (Lawrence and Scheske 1997, Plumlee 1999, Kefeni et al. 2017). AMD represents an environmental problem due to its high acidity, toxic metals, and sulfate contents. When deposits of calcite $\left(\mathrm{CaCO}_{3}\right)$, dolomite $\left(\mathrm{CaMg}\left[\mathrm{CO}_{3}\right]_{2}\right)$, and magnesite $\left(\mathrm{MgCO}_{3}\right)$ occur in proximity of acid-generating sulfide minerals, they can react and consume some of the acid generated during sulfide oxidation (Plumlee 1999). Otherwise, to fully suppress AMD generation, it is necessary to protect sulfide minerals from air, water, and bacteria (Kefeni et al. 2017).

Portland cement was previously reported as an excellent alternative for the encapsulation, as well as chemical fixation, of the toxic mobile elements in tailings (Nehdi and Tariq 2007, Rachman et al. 2018). Examples of its application include the fabrication of synthetic gravel (Zuccheratte et al.
2017), concrete pavements (Gayana and Chandar 2018), and cemented paste backfill (Lu et al. 2018). It is known that Portland cement can be mixed with aggregates (sand, gravel, and rock), water, and small amounts of chemical admixtures to make concrete (Aljerf 2015). Hence, our research interests are focused on the utilization of tailings as aggregates in the fabrication of concrete, particularly foamed concrete.

Foamed concrete is obtained by adding a foaming agent to the concrete mixture, resulting in a product with high flowability, low cement content, low aggregate usage and excellent thermal insulation (Amran et al. 2015). In the construction industry, prefabrication and modularization are preferred because they improve worksite productivity, decrease waste generation in site, and improve project return on investment (Construction 2011). In consequence, we proposed the fabrication of lightweight prefabricated panels (LPPs) that involve the use of tailings as replacement of aggregates in the foamed concrete. To further improve the concrete post-crack performance, polypropylene fibers are added during the preparation (Yin et al. 2015) and a fiberglass mesh is employed as reinforcement element.

\section{MATERIALS}

Mine tailings were provided from La Guitarra, a silver mine located at the Temascaltepec municipality, State of Mexico, Mexico, owned by First Majestic Silver (2015). The chemical analysis of the tailings was performed by the company following procedures according to the Official Mexican Standard NOM-141-SEMARNAT-2003 (SEMARNAT 2004). Contents of metals were determined by extraction and subsequent analysis through atomic absorption spectroscopy (AAS) whereas the neutralization and acidity potentials were determined by the modified acid base accounting (ABA) procedure. Both methodologies are based on the ASTM D3987 (ASTM 2012) and the modified ABA test (Lawrence and Wang 1997), respectively. Characterization details are summarized in tables I and II. 
TABLE I. HEAVY METALS CONCENTRATION IN MINE TAILINGS DETERMINED BY ATOMIC ABSORPTION SPECTROSCOPY (AAS).

\begin{tabular}{lcc}
\hline Element & $\begin{array}{c}\text { Measured concentration } \\
\text { by AAS }(\mathrm{mg} / \mathrm{L})\end{array}$ & $\begin{array}{c}\mathrm{MPL}^{\mathrm{a}} \\
(\mathrm{mg} / \mathrm{L})\end{array}$ \\
\hline $\mathrm{As}$ & $<0.005$ & $5.0^{*}$ \\
$\mathrm{Ba}$ & 0.24 & $100.0^{*}$ \\
$\mathrm{Be}$ & $<0.005$ & $1.22^{\dagger}$ \\
$\mathrm{Cr}$ & $<0.005$ & $5.0^{*}$ \\
$\mathrm{Ag}$ & $<0.005$ & $5.0^{*}$ \\
$\mathrm{~Pb}$ & $<0.005$ & $5.0^{*}$ \\
$\mathrm{Se}$ & $<0.005$ & $1.0^{*}$ \\
\hline
\end{tabular}

${ }^{a}$ Maximum permissible limit according to Mexican standards *NOM-052-SEMARNAT-2005 (SEMARNAT 2006), †NOM157-SEMARNAT-2009 (SEMARNAT 2011).

TABLE II. NEUTRALIZATION POTENTIAL (NP), ACIDITY POTENTIAL (AP), PH, AND HUMIDITY PERCENTAGE IN MINE TAILINGS OBTAINED FROM LA GUITARRA.

\begin{tabular}{cccc}
\hline $\begin{array}{c}\mathrm{NP}(\mathrm{kg} \text { of } \\
\left.\mathrm{CaCO}_{3} / \text { ton }\right)\end{array}$ & $\begin{array}{c}\mathrm{AP}(\mathrm{kg} \text { of } \\
\left.\mathrm{CaCO}_{3} / \text { ton }\right)\end{array}$ & $\mathrm{pH}$ & $\begin{array}{c}\text { Humidity } \\
(\%)\end{array}$ \\
\hline 0 & 2.22 & 3.89 & 14.3 \\
\hline
\end{tabular}

Because of their high water content, tailings were first sun-dried. Then, larger aggregates were separated using a sieve (mesh size of $2.5 \mathrm{~mm}$ ).

Type II Portland cement (CEMEX, Monterrey, Mexico), fiber glass mesh $\left(60 \mathrm{~g} / \mathrm{m}^{2}\right.$, FIBRAMALLA), foaming agent (Barracel, BASF), polypropylene fiber (Sika Fiber, SIKA), and vinyl sealant (Daraweld BA3S, GRACE) were bought at local hardware stores. Potable water was employed in all procedures.

Molds for the LPPs fabrication were built using four pieces of galvanized steel angle $(3 / 4 \times 3 / 4 \times$ $1 / 8$ in). These molds were secured with hexagonal bolts and nuts to obtain a rectangular form of 254 $\times 139.7 \times 12.7 \mathrm{~mm}$ (length $\times$ width $\times$ height $).$ It is highly important that molds are greased before the application of the concrete mixture to facilitate their cleaning and reuse.

\section{METHODS}

\section{Determination of the neutralization potential of LPPs}

Specimens were tested according to NOM141-SEMARNAT-2003 (SEMARNAT 2004), which is based on the modified ABA test (Lawrence and
Wang 1997), following the same procedure as in the tailings characterization.

\section{General procedure for LPPs fabrication}

The quantities employed to obtain the different test specimens are summarized in table III and were based on the previous experience of one of the authors in the masonry work with concrete (I.V.F.). Typically, mine tailings, polypropylene fiber, and cement are dry mixed in a bucket until a homogeneous mixture is obtained. Then, water and vinyl sealant are added. The mixing continues until a uniform paste forms. The foaming agent and water were mixed in a separate container until homogenization prior to their addition to the paste. The resulting product is poured into the molds to form their final shape. Afterwards, the fiberglass mesh $(254 \mathrm{~cm} \times 139.7 \mathrm{~cm})$ is placed into the mold. Finally, the concrete is cured every 24 hours with water for three days.

TABLE III. MATERIALS EMPLOYED IN THE FABRICATION OF DIFFERENT TEST SPECIMENS OF LPPS. NUMBERS CORRESPOND TO THE WEIGHT PERCENTAGE.

\begin{tabular}{lrrrr}
\hline Material & \multicolumn{4}{c}{ Test specimen } \\
\cline { 2 - 5 } & \multicolumn{1}{c}{1} & \multicolumn{1}{c}{2} & \multicolumn{1}{c}{3} & \multicolumn{1}{c}{4} \\
\hline Cement & 27.7 & 24.7 & 24.4 & 26.5 \\
Tailings & 41.6 & 44.4 & 44.0 & 47.7 \\
Water & 20.3 & 21.7 & 21.5 & 17.0 \\
Water/foaming agent & 5.5 & 5.9 & 4.9 & 5.3 \\
Foaming agent & 0.3 & 0.3 & 0.2 & 0.3 \\
Vinyl sealant & 4.6 & 3.0 & 4.9 & 3.2 \\
\hline
\end{tabular}

\section{Characterization of LPPS}

The apparent density, thermal conductivity, water vapor permeability, humidity adsorption, and water absorption were measured for the LPPs because Mexican Official Standard NOM-018-ENER-2011 (SENER 2011) requires them to be reported for the commercialization of thermal insulating materials, with no specified reference values. Additionally, the flexural strength of panels was determined.

The apparent density is defined as the ratio between the apparent volume (i.e., including voids) and the mass of the sample. The following equation was employed:

$\rho_{a p}=\frac{m}{V}$ 
where $\rho_{\text {ap }}$ is the apparent density $\left(\mathrm{kg} / \mathrm{m}^{3}\right), m$ is the mass of the specimen $(\mathrm{kg})$, and $V$ is the volume of the specimen $\left(\mathrm{m}^{3}\right)$.

Thermal conductivity was determined by using a quasicubic arrangement, as proposed by Díaz and Tibaquirá (2008). Five sides of the cube consist of expanded polystyrene (thermal insulator) with a panel that is placed at the top side. A lamp, inside the cube, was used as the heat source, and temperature differences were measured using an infrared thermometer. Finally, thermal conductivity was estimated using the Fourier's equation of heat conduction:

$Q_{\text {cond }}=-k A \frac{\Delta T}{\Delta X}$

where $Q_{\text {cond }}$ is the heat flow rate by conduction (W), $k$ is the thermal conductivity of the panel $(\mathrm{W} / \mathrm{m} \mathrm{K})$, $A$ is the cross-sectional area normal to direction of heat flow $\left(\mathrm{m}^{2}\right), \Delta T$ is the temperature difference $(\mathrm{K})$, and $\Delta X$ is the panel thickness $(\mathrm{m})$.

For water absorption experiments, test specimens were submerged horizontally in a container with water at $20 \pm 1{ }^{\circ} \mathrm{C}$. After $24 \mathrm{~h}$, water was removed and the specimen suspended to drain for $10 \mathrm{~min}$. The weight difference, before and after submersion, corresponds to the water absorbed by the panel.

Moisture adsorption was determined by placing the specimens inside an aluminum chamber with relative humidity of $100 \%$ and temperature of $20^{\circ} \mathrm{C}$ for $24 \mathrm{~h}$. The weight difference, before and after the treatment, corresponds to the moisture adsorbed by the specimen.

Water vapor permeability was measured following a procedure similar to the ASTM E96/E96M method (ASTM 2016a). A test dish impermeable to water was filled with distilled water and the test specimen was attached to the dish by sealing. Distance from the water level to the test specimen was $20 \mathrm{~mm}$. This assembly was placed on a horizontal surface and weighed periodically to determine the change in mass as a function of time. A slope value was determined from the linear regression of the straight line obtained. When the slope value is divided by the test area (cup mouth area), the rate of water vapor transmission (WVT) of the specimen is obtained. Later, permeance was obtained using the following equation:

Permeance $=\frac{W V T}{S\left(R_{1}-R_{2}\right)}$

where $S$ is the saturation vapor pressure at the test temperature $\left(25^{\circ} \mathrm{C}\right), R_{1}$ is the relative humidity in the dish, and $R_{2}$ is the relative humidity at the vapor sink.
Finally, tension tests were carried out using an INSTRON 3360 Series Dual Column Tabletop Testing System. A given panel was supported near the ends $(2.54 \mathrm{~cm})$ and a central load was applied at $50 \mathrm{~mm} /$ min until the specimen fracture.

\section{RESULTS AND DISCUSSION}

\section{Toxicity of LPPs}

From data in table $\mathbf{I}$, it is clear that mine tailings from La Guitarra do not represent a hazardous waste in terms of their metals' content according to Mexican standards (SEMARNAT 2004). However, their lack of neutralization potential along with their acidity potential $\left(2.22 \mathrm{~kg}\right.$ of $\mathrm{CaCO}_{3}$ per ton of tailings) made necessary to stabilize them by making foamed concrete. After fabrication of the LPPs, the NP and AP of the panels were determined to evaluate their potential as generators of AMD. A value of NNP = $193 \pm 1.5$ was obtained, which indicates that LPPs do not represent a hazardous waste in terms of the Mexican standards (SEMARNAT 2004). It has been mentioned that the effectiveness of Portland cement to stabilize mine tailings is mainly derived by the encapsulation, as well as chemical fixation, of their toxic components (Nehdi and Tariq 2007, Rachman et al. 2018).

\section{Characterization of LPPs}

The properties measured for every test specimen after characterizations are shown in table IV.

It is worth to mention that early experiments lead us to the use of a fiberglass mesh as reinforcement element in the panels. The mesh accounted for up to $95 \%$ of the flexural strength in the panels. As can be seen in table IV, minimal variations between the test specimens were found; also, if the mesh is not used, cracks appear in the PPLs. Thus, we decided to use the mesh, then statistical changes were difficult to observe. The properties of foamed concrete as a function of their composition was previously reviewed in the literature (Amran et al. 2015, Ma and Chen 2016) and a similarly extensive study was not considered necessary for LPPs.

According to their apparent density values $(<1800$ $\mathrm{kg} / \mathrm{m}^{3}$ ), LPPs correspond to lightweight concrete. In general, flexural strength in concrete is about 10 to $20 \%$ of its compressive strength (NRMCA 2000). This indicates that specimens 1-4 are not suitable for structural applications neither by density (ASTM 2016b) nor strength (NRMCA 2003). However, LPPs are not intended for a structural application, but as 
TABLE IV. PROPERTIES MEASURED FOR THE TEST SPECIMENS OBTAINED.

\begin{tabular}{cccccccc}
\hline $\begin{array}{c}\text { Test } \\
\text { specimen }\end{array}$ & $\begin{array}{c}\text { Flexural } \\
\text { strength } \\
(\mathrm{MPa})\end{array}$ & $\begin{array}{c}\text { Apparent } \\
\text { density } \\
\left(\mathrm{kg} / \mathrm{m}^{3}\right)\end{array}$ & $\begin{array}{c}\text { Water } \\
\text { absorption } \\
(\% \text { mass })\end{array}$ & $\begin{array}{c}\text { Humidity } \\
\text { absorption } \\
(\% \text { mass })\end{array}$ & $\begin{array}{c}\text { Permeance } \\
\text { (perm) }\end{array}$ & $\begin{array}{c}\text { Thermal conduc- } \\
\text { tivity (W/m K) }\end{array}$ & NNP \\
\hline 1 & 5.76 & 613.4 & 71.9 & 14.2 & 31.47 & 0.162 & 195 \\
2 & 5.78 & 656.7 & 59.3 & 8.2 & 26.9 & 0.163 & 192 \\
3 & 5.78 & 853.1 & 46.4 & 2.1 & 43.54 & 0.159 & 192 \\
4 & 5.89 & 725.0 & 59.4 & 5.4 & 22.01 & 0.153 & 194 \\
\hline
\end{tabular}

NNP: net neutralization potential.

an alternative for non-structural applications such as housing (insulating walls, sidings, or roof material).

Thermal conductivity values $(k)$ are not directly comparable with other foamed concrete systems. This is due to the addition of mine tailings as aggregates. The comparison of typical thermal conductivity values for foamed concretes (Asadi et al. 2018) in the density range of $400-1600 \mathrm{~kg} / \mathrm{m}^{3}(0.15-0.57$ $\mathrm{W} / \mathrm{m} \mathrm{K}$ ) indicates that LPPs 1-4 are similar in terms of thermal behavior $(0.15-0.16 \mathrm{~W} / \mathrm{m} \mathrm{K})$. Foamed concrete is considered an excellent thermal insulator because of its low $k$ values. Such behavior is mainly due to the enhanced amount of air inside the cement matrix (Asadi et al. 2018).

The lack of water and moisture absorption studies in foamed concrete with tailings made necessary to compare our results with nearly equivalent systems. Ma and Chen (2016) have reported the properties of foamed concrete (target density: $550 \mathrm{~kg} / \mathrm{m}^{3}$ ) made of ordinary Portland cement, silica fume, water, polypropylene fiber, a type of naphtalene-based superplasticizer and foam stabilizer agents. Water absorption, by volume, determined after $48 \mathrm{~h}$ of concrete soaking is $68.5 \%$ and the moisture absorption value obtained at $100 \%$ relative humidity is $46.4 \mathrm{~kg} /$ $\mathrm{m}^{3}$. Those values are closely related to the obtained for test specimens 1-4 confirming the seamless integration of tailings in foamed concrete.

The water vapor permeance of materials is commonly reported in the construction trade with the unit "perm" rather than their SI equivalent $\left(\mathrm{g} / \mathrm{Pa} \mathrm{s} \mathrm{m}^{2}\right)$. The values obtained for the LPPs $(>10$ perm) indicate that panels are classified as vapor permeable. This characteristic is convenient for their use in certain hygrothermal conditions (Lstiburek 2002).

\section{CONCLUSIONS}

Mine tailings obtained from a silver mine were mixed with Portland cement, water, and other additives to obtain foamed concrete, which is useful in the fabrication of LPPs. Their properties were similar to those reported for common foamed concrete, indicating that tailings are suitable as a replacement of aggregates in foamed concrete mixtures. Moreover, characterization indicates that LPPs have a net neutralization potential of 192, proving the stabilization of tailings and that there is no risk of AMD generation.

Lottermoser (2011) describes waste-management practices with a hierarchy in the following order: (i) prevention, (ii) reuse, (iii) recycling, (iv) energy recovery, and $(v)$ treatment and disposal. As tailing's generation is inevitable, their use as aggregates replacement in foamed concrete is a promising alternative for their handling. Other uses of foamed concrete include their use as backfill material for heat preservation pipes, foundation for the highway roads, fire insulation, trench reinstatement, etc. (Tan et al. 2014, Amran et al. 2015). This leaves us with plenty of opportunities remaining unexplored in the replacement of aggregates with mine tailings.

\section{ACKNOWLEDGMENTS}

We would like to recognize the support of Secretaría de Energía-Consejo Nacional de Ciencia y Tecnología (Fondo SENER-CONACyT), project 266492, Engineering and science applied to the semidesert energy sector in the north of the country, to perform this study.

\section{REFERENCES}

Aljerf L. (2015). Effect of thermal-cured hydraulic cement admixtures on the mechanical properties of concrete. Interceram. Int. Cer. Rev. 64, 346-356. https://doi. org/10.1007/BF03401142 
Amran Y.M., Farzadnia N. and Ali A.A. (2015). Properties and applications of foamed concrete; A review. Constr. Build. Mater. 101, 990-1005. https://doi.org/10.1016/j. conbuildmat.2015.10.112

Asadi I., Shafigh P., Hassan Z.F.B A. and Mahyuddin N.B. (2018). Thermal conductivity of concrete-A review. J. Build. Eng. 20, 81-93. https://doi.org/10.1016/j. jobe.2018.07.002

ASTM (2012). D3987-12. Standard practice for shake extraction of solid waste with water. American Society for Testing and Materials International, West Conshohocken, PA, USA, 4 pp. https://doi.org/10.1520/ D3987-12

ASTM (2016a). E96/E96M-16. Standard test methods for water vapor transmission of materials. American Society for Testing and Materials, West Conshohocken, PA, USA, 14 pp. https://doi.org/10.1520/ E0096_E0096M-16

$\operatorname{ASTM}(2016 \mathrm{~b})$. C1705/C1705M-09R16. Standard specification for structural cementitious panels. American Society for Testing and Materials, West Conshohocken, PA, USA, 5 pp. https://doi.org/10.1520/C1705_ C1705M-09R16

Aznar-Sánchez J., García-Gómez J., Velasco-Muñoz J. and Carretero-Gómez A. (2018). Mining waste and its sustainable management: Advances in worldwide research. Minerals 8 (7), 284. https://doi.org/10.3390/ $\min 8070284$

Construction (2011). Smart market report: Prefabrication and modularization-Increasing productivity in the construction industry. McGraw Hill Construction, Bedford, MA, USA, $56 \mathrm{pp}$.

First Majestic Silver (2015). La Guitarra silver mine, Temascaltepec, Mexico, NI 43-101. Technical report on mineral resource and mineral reserve update. First Majestic Silver Corporation, Temascaltepec, Estado de México, Mexico, 183 pp.

Díaz N.F. and Tibaquirá J.E. (2008). Método para la estimación experimental de la conductividad térmica de algunos materiales comunes en Colombia para aplicaciones HVAC/R. Scientia et Technica 2 (39), 464-469.

Gayana B. and Chandar K.R. (2018). Sustainable use of mine waste and tailings with suitable admixture as aggregates in concrete pavements-A review. Adv. Concr. Constr. 6 (3), 221-243. https://doi.org/10.12989/ acc.2018.6.3.221

Gorman M.R. and Dzombak D.A. (2018). A review of sustainable mining and resource management: Transitioning from the life cycle of the mine to the life cycle of the mineral. Resour. Conserv. Recy. 137, 281-291. https://doi.org/10.1016/j.resconrec.2018.06.001

Jain M.K. and Das A. (2017). Impact of mine waste leachates on aquatic environment: A review. Curr.
Pollution Rep. 3 (1), 31-37. https://doi.org/10.1007/ s40726-017-0050-z

Kefeni K.K., Msagati T.A. and Mamba B.B. (2017). Acid mine drainage: Prevention, treatment options, and resource recovery: A review. J. Clean. Prod. 151, 475-493. https://doi.org/10.1016/j.jclepro.2017.03.082

Kossoff D., Dubbin W., Alfredsson M., Edwards S., Macklin M. and Hudson-Edwards K.A. (2014). Mine tailings dams: characteristics, failure, environmental impacts, and remediation. Appl. Geochem. 51, 229-245. https://doi.org/10.1016/j.apgeochem.2014.09.010

Lawrence R.W. and Scheske M. (1997). A method to calculate the neutralization potential of mining wastes. Environ. Geol. 32 (2), 100-106. https://doi.org/10.1007/ s002540050198

Lawrence R.W. and Wang Y. (1997). Determination of neutralization potential in the prediction of acid rock drainage. Proceedings of the Fourth International Conference on Acid Rock Drainage May 30-June 6, Vancouver, BC, Canada, 449-464.

Lottermoser B G. (2011). Recycling, reuse, and rehabilitation of mine wastes. Elements 7 (6), 405-410. https:// doi.org/10.2113/gselements.7.6.405

Lstiburek J. (2002). Moisture control for buildings. ASHRAE J. 44 (2), 36-41.

Lu H., Qi C., Chen Q., Gan D., Xue Z. and Hu Y. (2018). A new procedure for recycling waste tailings as cemented paste backfill to underground stopes and open pits. J. Clean. Prod. 188, 601-612. https://doi.org/10.1016/j. jclepro.2018.04.041

Ma C. and Chen B. (2016). Properties of foamed concrete containing water repellents. Constr. Build. Mater. 123, 106-114. https://doi.org/10.1016/j.conbuildmat.2016.06.148

Nehdi M. and Tariq A. (2007). Stabilization of sulphidic mine tailings for prevention of metal release and acid drainage using cementitious materials: A review. J. Environ. Eng. Sci. 6 (4), 423-436. https://doi.org/10.1139/ s06-060

NRMCA (2000). CIP-16. Flexural strength concrete. National Ready Mixed Concrete Association, Silver Spring, MD, USA, 2 pp.

NRMCA (2003). CIP-36. Structural lightweight concrete. National Ready Mixed Concrete Association, Silver Spring, MD, USA, 2 pp.

Páez-Osuna F., Bojórquez-Leyva H., Bergés-Tiznado M., Rubio-Hernández O., Fierro-Sañudo J., RamírezRochín J. and León-Cañedo J. (2015). Heavy metals in waters and suspended sediments affected by a mine tailing spill in the upper San Lorenzo River, Northwestern Mexico. B. Environ. Contam. Tox. 94 (5), 583-588. https://doi.org/10.1007/s00128-015-1473-0 
Plumlee G.S. (1999). The environmental geochemistry of mineral deposits, part A. Processes, techniques, and health issues. In: The environmental geology of mineral deposits (Plumlee G.S. and Logsdon M.J., Eds.). Society of Economic Geologists, Littleton, CO, USA, 71-116.

Rachman R.M., Bahri A.S. and Trihadiningrum Y. (2018). Stabilization and solidification of tailings from a traditional gold mine using Portland cement. Environ. Eng. Res. 23 (2), 189-194. https://doi.org/10.4491/ eer.2017.104

Schoenberger E. (2016). Environmentally sustainable mining: The case of tailings storage facilities. Resour. Policy 49, 119-128. https://doi.org/10.1016/j.resourpol.2016.04.009

SEMARNAT (2004). Norma Oficial Mexicana NOM141-SEMARNAT-2003. Que establece el procedimiento para caracterizar los jales, así como las especificaciones y criterios para la caracterización y preparación del sitio, proyecto, construcción, operación y postoperación de presas de jales. Secretaría de Medio Ambiente y Recursos Naturales. Diario Oficial de la Federación, 13 de septiembre.

SEMARNAT (2006). Norma Oficial Mexicana NOM052-SEMARNAT-2005. Que establece las características, el procedimiento de identificación, clasificación y los listados de los residuos peligrosos. Secretaría de Medio Ambiente y Recursos Naturales. Diario Oficial de la Federación, 23 de junio.

SEMARNAT (2011). Norma Oficial Mexicana NOM157-SEMARNAT-2009. Que establece los elementos y procedimientos para instrumentar planes de manejo de residuos mineros. Secretaría de Medio Ambiente y Recursos Naturales. Diario Oficial de la Federación, 30 de agosto.

SENER (2011). Norma Oficial Mexicana NOM-018-SENER-2011. Aislantes térmicos para edificaciones. Características y métodos de prueba. Secretaría de Energía. Diario Oficial de la Federación, 14 de diciembre.

Tan X., Chen W., Hao Y. and Wang X. (2014). Experimental study of ultralight $(<300 \mathrm{~kg} / \mathrm{m} 3)$ foamed concrete. Adv. Mater. Sci. Eng. 2014. https://doi. org $/ 10.1155 / 2014 / 514759$

Yin S., Tuladhar R., Shi F., Combe M., Collister T. and Sivakugan N. (2015). Use of macro plastic fibres in concrete: A review. Constr. Build. Mater. 93, 180-188. https://doi.org/10.1016/j.conbuildmat.2015.05.105

Zuccheratte A.C.V., Freire C.B. and Lameiras F.S. (2017). Synthetic gravel for concrete obtained from sandy iron ore tailing and recycled polyethyltherephtalate. Constr. Build. Mater. 151, 859-865. https://doi.org/10.1016/j. conbuildmat.2017.06.133 